\title{
O ciberespaço nas páginas do livro infantojuvenil
}

\author{
Leo Cunha ${ }^{1}$
}

\begin{abstract}
Resumo
Por meio de análises acerca do processo criativo concebido para a criação da obra Perdido no Ciberespaço (2007), com autoria atribuída ao realizador deste estudo, o presente trabalho tem por objetivo traçar um percurso pelo qual possa ser possível captar e compreender os diálogos existentes entre de exemplares contemporâneos de literatura infantil e juvenil e as novas tecnologias da comunicação, com foco especial para a internet e para a realidade da cibercultura.
\end{abstract}

\begin{abstract}
By means of analyses about the creative process designed for the creation of the work Perdido no Ciberespaço (2007), with authorship attributed to the director of this study, the present article aims to trace a path by which it may be possible to capture and understand existing dialogues between copies of contemporary children's literature and new communication technologies, with special focus to the internet and to the reality of cyberculture.
\end{abstract}

PALAVRAS-CHAVE: processo criativo; literatura infanto-juvenil; redes sociais; cibercultura

KEYWORDS: creative process; children's literature; social networks; cyberculture

\footnotetext{
${ }^{1}$ Doutor em Cinema pela na UFMG. Escritor, jornalista e professor universitário. Autor de Literatura Infantil e Juvenil. Vários de seus livros receberam prêmios Jabuti, Nestlé, João de Barro, FNLIJ.
} 


\section{O ciberespaço nas páginas do livro infantojuvenil}

Hoje em dia, os adolescentes, pré-adolescentes e uma quantidade razoável de crianças circulam diariamente no ciberespaço: trocam emails e torpedos SMS, compartilham fotos e vídeos, publicam blogs, conversam pelo MSN e Facebook, exploram o YouTube, se arriscam no Twitter, Flicker e outras redes sociais. A Internet faz parte da realidade cotidiana da juventude contemporânea, que mal consegue imaginar como a vida era possível antes da rede.

E quando pegam um livro de literatura infantojuvenil, por iniciativa própria ou por solicitação da escola, que universo esses leitores encontram nas histórias? Em que medida os personagens e situações ali encontrados se assemelham ao universo comunicativo em que vivem os leitores? Este artigo aborda tais questões, a partir de um viés bastante pessoal: o processo de criação do meu livro Perdido no Ciberespaço, publicado em 2007 pela editora Larousse.

Antes de apresentar e discutir esse processo, porém, cabe um breve panorama do que é encontrado atualmente nos livros de literatura para crianças e jovens. Pesquisando em livrarias, bibliotecas e catálogos de editoras, percebi três formas principais como o ciberespaço (e, junto com ele, a cibercultura) marca presença nessas obras.

a) Existem os livros que usam a Internet como pano de fundo. Neles, a história costuma transitar por temas (família, amigos, escola, solidão, amadurecimento, amor etc) e gêneros (aventura, mistério, romance, terror, entre outros) já tradicionais da literatura infantojuvenil, mas temos personagens que, em seu cotidiano familiar e/ou escolar navegam na internet, falam sobre ela, trocam emails, participam de chats, comentam sobre blogs, sites interessantes, vídeos do YouTube e outros pontos do ciberespaço.

É o caso de Coração na rede, trama romântica de Telma Guimarães Castro Andrade que envolve mistério, traição e os dilemas da identidade em tempos de Internet. É também o que ocorre em Ataque do Comando P.Q., de Moacyr Scliar. Aqui, temos a típica aventura de um grupo de adolescentes às voltas com um hacker que invadiu a prefeitura da cidade e deixou um código secreto. Para desvendar o mistério, o jovem Caco, seu professor de literatura, Roberto, e a turma irão mergulhar na leitura do livro O triste fim de Policarpo Quaresma, de Lima Barreto.

Em Amigos pra cachorro, de Silvana Costa, a jovem Mel se muda para um prédio que não aceita cachorros e precisa se desfazer de seu querido labrador Hermes. Após publicar um classificado no jornal, Mel descarta vários candidatos, mas acaba gostando de Tales, com quem troca diversos emails até se encontrar, ao final do livro, momento em que descobriremos uma peculiaridade importante dos relacionamentos virtuais. 
Os exemplos são vários, mostrando que os escritores conhecem a realidade tecnológica e comunicacional dos leitores contemporâneos e se dispõem a mergulhar nas diversas formas como os chips reinventam o nosso dia a dia. Não por acaso, este é o subtítulo de um livro juvenil do qual participei recentemente: Internautas: os chips reinventando o nosso dia a dia. Proposto e organizado por Luiz Antonio Aguiar, o livro reúne 20 contos, a grande maioria de autores já bem identificados com a literatura infantojuvenil, como Celso Sisto, Luciana Sandroni, Luís Pimentel, Rosa Amanda Strausz, Rosana Rios, Sandra Pina, entre outros. No conto "Olhos azuis", por exemplo, Angela Leite de Souza põe um notebook na posição de salvador (ou não?) de uma garota sequestrada. Em "voodeicaro.blogspot.com", de Caio Riter, o personagem se apresenta por meio de seu avatar, ou seu nick, e viaja pela mitologia grega, com escalas em obras populares entre os jovens, como As crônicas de Nárnia e O Senhor dos Anéis. Mais apocalíptico, Rogério Andrade Barbosa traz "Ligadão", um conto aterrorizante sobre um garoto viciado em internet que vê seu corpo entrar em colapso. O próprio Luiz Antonio apostou no caminho oposto ao de Rogério, ao imaginar, em "Desconectado, ou é possível ser feliz sem internet?" um personagem que, em pleno século XXI, vive (quase) totalmente alheio à cibercultura. Já em meu conto, "Gostos e desejos e mentiras", relato, com uma pequena dose de exagero, um caso assustador ocorrido com minha irmã, quando um belo dia viu seu Orkut e Facebook invadidos por estranhas mensagens sugerindo que sua filha de oito anos tinha morrido.

b) Outros livros, porém, não só situam suas tramas e personagens num mundo altamente conectado, como usam a internet para atualizar formatos já existentes na tradição da literatura infantojuvenil.

Um desses formatos é o diário, que há décadas faz sucesso entre os jovens, como no caso de Minha vida de menina, de Helena Morley e $O$ diário de Anne Frank. Isso para não falar dos mais recentes, como Diário de Biloca, de Edson Gabriel Garcia, Sabe de uma coisa?, de Vivina de Assis Viana, O diário de Tati, de Heloísa Pèrissé, ou ainda os importados Diário de uma princesa, Diário de um adolescente hipocondríaco etc.

Em tempos de internet, o mercado foi invadido por livros escritos como diários virtuais, geralmente na forma de blogs. Há opções para todas as idades, gêneros e graus, mas predominam os femininos: O blog da Mila, O blog da Cacau, O blog da Ritoca, O blog da Marina. José Roberto Torero optou por criar o Blog do Lelê, seu sobrinho imaginário que já foi personagem de outros textos. Logo no início do livro, Lelê explica:

Eu tenho oito anos e esse é o meu primeiro livro. Ele tem um monte de histórias que eu coloquei no meu blog. Blog é assim que nem um diário, só que a gente escreve no computador. O chato do blog é que só quem tem computador é que pode ler. Mas agora as histórias vão ficar nas folhas deste livro aqui, e aí mais gente vai poder ler. Livro é legal. A gente não precisa ligar na tomada e ele não quebra (se bem que de vez em quando os meus rasgam, mas é sem querer).

Em que pesem as semelhanças, não há como desconsiderar a transformação essencial que se 
opera nessa troca de suporte: os diários em papel (caderninhos, blocos, agendas) sempre trouxeram uma aura de segredo, de confissões e desabafos para não serem lidos por ninguém; alguns chegam a ter cadeados. Já os blogs, ainda que tragam confissões e desabafos, já não têm nada de secreto, pois estão ali, expostos na rede, para quem quiser ler.

Assim, nos livros infantis que apostam no diário em papel, o grande risco que paira sobre os personagens é o terem seus segredos descobertos pelos pais, irmãos, amigos, colegas. Já nos livros sobre blogs, os riscos são outros: por um lado, o arrependimento pela exposição de segredos e intimidades; por outro, o medo de não serem lidos!

Outro formato bastante sedimentado na literatura infantojuvenil é a troca de correspondência, como no adorável Ana e Pedro, escrito em parceria por Vivina de Assis Viana e Ronald Claver. No livro, uma garota paulista e um garoto mineiro trocam cartas, lembranças, desejos e declarações de amor. Outro exemplo marcante, inclusive pela produção visual impecável, é Griffin e Sabine - uma correspondência extraordinária, de Nick Bantock.

Em tempos de internet, este formato ressurge, frequentemente, como trocas de emails entre personagens. Em sinos_e_queijos.com, de Angela Leite de Souza e Lino de Albergaria, o menino é paulista e a menina é mineira, invertendo o que ocorria em Ana e Pedro. Inácio e Estefânia chegam a trocar uma carta convencional, mas se comunicam mesmo é por emails e, a partir de certo momento, por mensagens do MSN. Os assuntos são vários, desde o namorico à distância até a relação entre culturas antigas e contemporâneas.

Em Só entre nós, de Júlio Emílio Braz e Janaína Vieira, os meios físicos e virtuais convivem. O livro é uma atualização do célebre romance entre Abelardo e Heloísa, transportado do século XI para os caminhos do amor virtual. A troca de emails surge mesclada à troca de cartas numa viagem de companheirismo e autodescoberta.

Mas há livros infantojuvenis contemporâneos que ainda se apegam à tradicional troca de correspondências, como ressalta Sersi Bardari, acerca do livro De Paris, com amor, escrito por Lino de Albergaria.

Fim do século XX, 1997, o mundo já se comunica por correio eletrônico e salas virtuais de bate-papo. Os programas de mensagens instantâneas, do tipo MSN e Windows Live, da Microsoft, não demorariam a chegar ao mercado e a se popularizarem via internet. Inicia-se o tempo em que a privacidade e 0 anonimato no que se refere à troca de correspondência são paradoxalmente possíveis e ilusórios. Nessa época de tecnologia avançada, na qual namoro e sexo virtual são práticas corriqueiras, dois jovens irão protagonizar um delicado romance epistolar, por meio de suportes convencionais, isto é, cartões postais, cartas e bilhetes. (BARDARI, 2008, p. 213-214) 
c) Em Perdido no Ciberespaço, minha proposta foi bem diferente das apresentadas acima. A ideia era trazer, para as páginas do livro, uma narrativa que se apropriasse da linguagem, do imaginário e mesmo da topografia do ciberespaço, fazendo com que o leitor se sentisse dentro da internet, e mesmo um pouco perdido no mundo virtual, como o narrador.

Flertando com a ideia de autofiç̧ão ${ }^{2}$, criei um narrador chamado Leo Cunha, um escritor novato no ciberespaço, que se sente desorientado naquele tempo, naquele espaço e naquela linguagem, um pouco como eu me senti em meus primeiros contatos com a Internet.

O livro é um desdobramento lúdico, leve e bem humorado da minha dissertação de mestrado, desenvolvida no curso de Ciência da Informação da UFMG, entre 1996 e 1999. Num momento em que o tema era praticamente inédito na universidade brasileira, a pesquisa se debruçou sobre os recursos que a publicação eletrônica (naquele momento, basicamente em disquetes, CD-Roms e páginas em html da Internet) propiciava à narrativa literária.

Um dos referenciais teóricos da minha pesquisa foi o livro seminal e visionário do professor George P. Landow, acerca da publicação eletrônica, Hypertext: the convergence of contemporary critical theory and technology. Publicado em 1992, o livro já sublinhava a importância de noções como hipertexto, interatividade, multimídia e convergência. Segundo Landow, as novas tecnologias propiciavam uma imbricação de formas discursivas (texto, imagem, som, vídeo, simulações, etc), mas também da confluência dos próprios equipamentos (jornais, livros, rádios, TVs, computadores, celulares), além de um tipo menos evidente de convergência: aquela que se manifestava - já naquele nascedouro da World Wide Web - entre as formas discursivas possibilitadas pela publicação eletrônica e vários pontos das teorias literária e semiológica contemporâneas.

Sobre este último tópico, alguns exemplos podem ser destacados. No pensamento de Roland Barthes, Landow buscou a noção da "lexia"3, a ideia das redes de textos, a rejeição às narrativas sequenciais e perspectivas unitárias, e a contraposição entre "textos legíveis" e "textos escrevíveis". Em Jacques Derrida, Landow recorria à ideia de argumentação não-linear, texto fragmentado, colunas paralelas e outros elementos que sugeriam uma "escrita topográfica", como se Derrida já estivesse prevendo, na década de 70, a publicação em um meio fluido e as possibilidades do hipertexto. Em Mikhail Bakhtin, Landow também enxergava uma concepção de textualidade que antecipa 0 hipertexto, em vários aspectos. Para Bakhtin, os textos são polifônicos, relacionais, inacabados e

\footnotetext{
${ }^{2}$ O conceito de autoficção, proposto por Serge Doubrovsky (2001), como uma variante pós-moderna da autobiografia, implica na apresentação de memórias do autor de forma a entrelaçar a realidade vivida e imaginada, ou seja, salpicando as lembranças com invenção e especulação.

${ }^{3} \mathrm{Na}$ década de 1960, Barthes utiliza o termo lexia para designar, em determinado texto, um fragmento, um bloco curto de significação que se interrelaciona com os outros fragmentos do texto. Mais recentemente, o termo vem sendo utilizado por teóricos do hipertexto para designar cada um dos "nós" (nodes) de um hipertexto, ou seja, cada "página" ou "tela", que é uma unidade significativa em si mesma, mas está interligada a outras, através de links.
} 
alteráveis, funcionando como um inesgotável diálogo entre gêneros, épocas, formas, línguas.

Sintetizando, Landow argumentava que os conceitos da teoria pós-estruturalista e os conceitos de teóricos da informática, como Theodor Nelson e Andries Van Dam, entrelaçavam-se quando todos eles defendem "o abandono dos sistemas conceituais fundados nas ideias de centro, margem, hierarquia e linearidade, substituindo-as pelas de multilinearidade, nós, links e redes." (LANDOW, 1992, p. 02).

Ao mesmo tempo, minha dissertação não ignorava algumas dificuldades e dilemas que eram introduzidos ou amplificados pela escrita e leitura virtuais, como por exemplo: o risco da invasão de privacidade, da alteração fraudulenta e não autorizada de páginas e sites da Internet; o perigo dos vírus eletrônicos; além do risco de uma sensação de "desorientação", gerado pelas novas configurações espaciais e temporais no ciberespaço.

Para explorar algumas das características citadas acima, meu livro Perdido no ciberespaço ${ }^{4}$ contou com a imprescindível participação do ilustrador e designer Guto Lins. Logo nas primeiras páginas, antes do início da narrativa propriamente dita, Guto criou 2 páginas em que se vê simplesmente uma barra de inicialização, em progresso, como se o livro estivesse sendo "carregado". Na primeira, 19\%, na segunda, $72 \%$

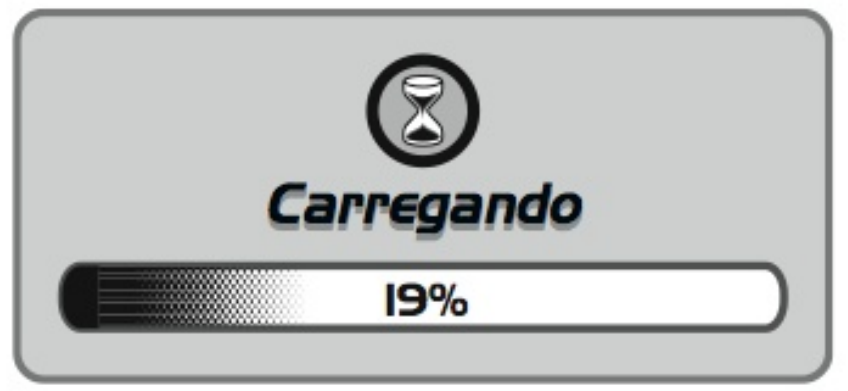

Só então se inicia, efetivamente, a narrativa, com um enorme pedido de "Socorro", vindo do computador. A partir daí, o narrador dirige-se diretamente ao leitor, até o final do livro. O narrador Leo Cunha está perdido na Internet, não consegue entender onde está, nem como sair dali, e pede ajuda ao leitor.

\footnotetext{
${ }^{4}$ Desde 0 início do processo de criação do livro, eu decidi que iria usar um título que parodiasse algum filme ou seriado televisivo, porque a paródia, a citação, a intertextualidade são marcas fortes da narrativa hipemidiática. Minha ideia inicial era usar o título "SOS, tem um louco no ciberespaço" (que é uma das frases do livro), brincando com a comédia do Mel Brooks, SOS, tem um louco no espaço (Spaceballs, 1987). Mas tive o receio de que poucos leitores iriam identificar e mesmo entender a brincadeira. Então parti para a paródia de outro título, do seriado Perdidos do Espaço (Lost in Space, 1965 a 1968). Mesmo que os leitores não "pescassem" a alusão, o título se sustentava bem.
} 


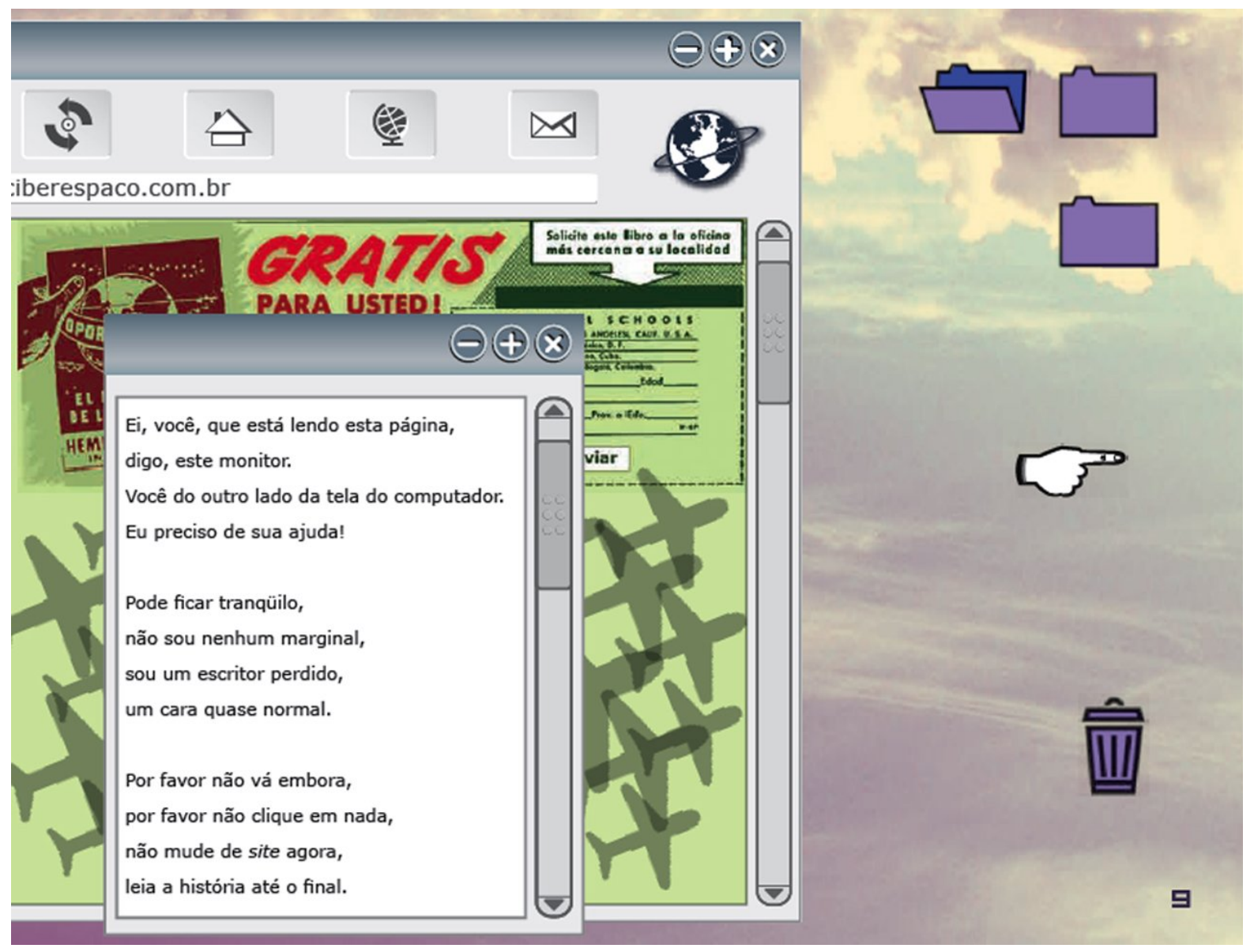

O projeto gráfico de Guto Lins reforça a ambiguidade espacial: o que o leitor está vendo é um livro ou é a tela de um computador? Ao longo das páginas, surgirão diversos elementos visuais típicos do ciberespaço: os menus, as barras de rolagem, as pastas, a lixeira, a "mãozinha" indicando ações ou links.

Enquanto isso, o texto remete sem - preocupações didáticas - a várias questões discutidas na dissertação, ligadas ao ciberespaço e à navegação virtual. Entre elas: 
- A interatividade e os chamados emoticons:

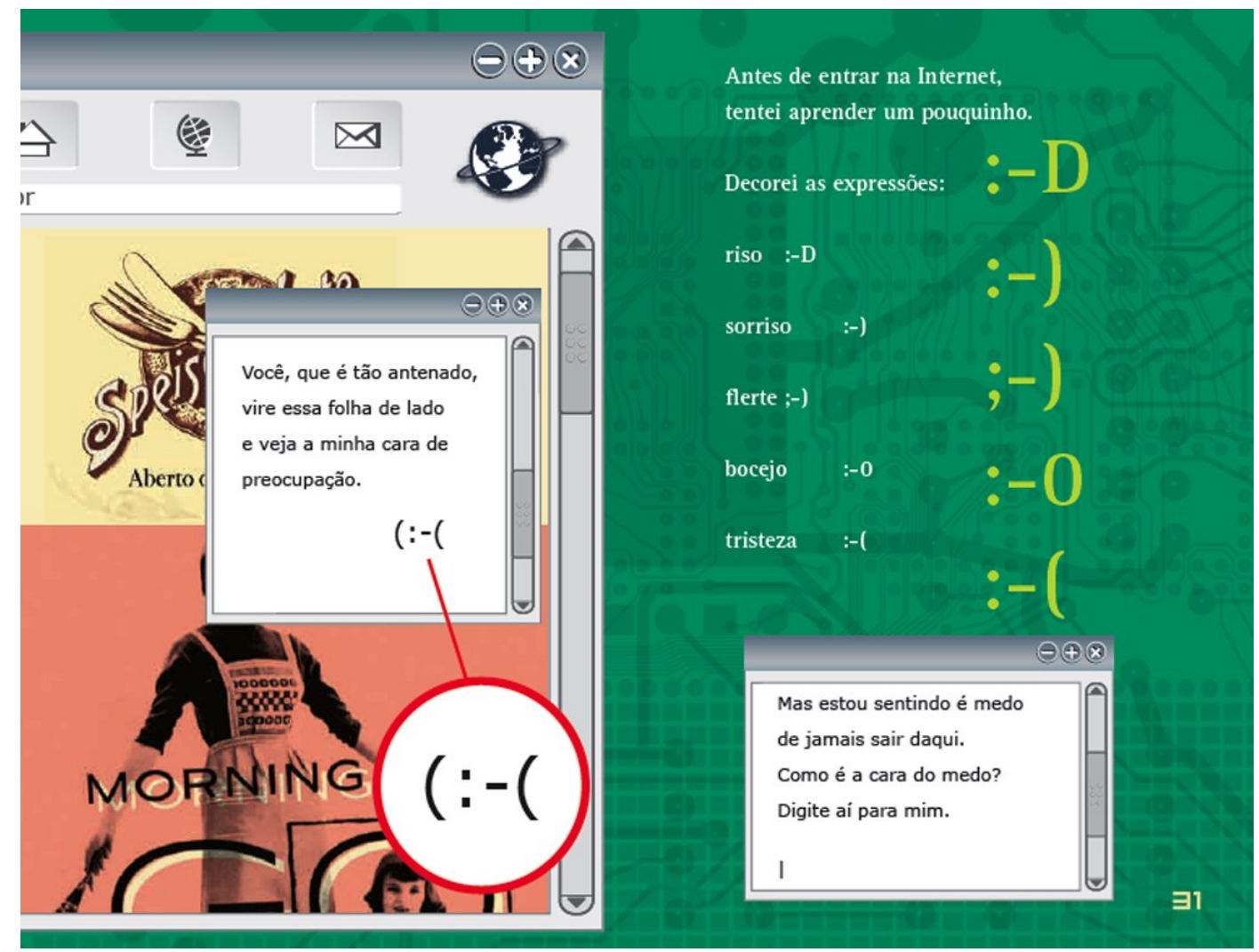

- O hipertexto:

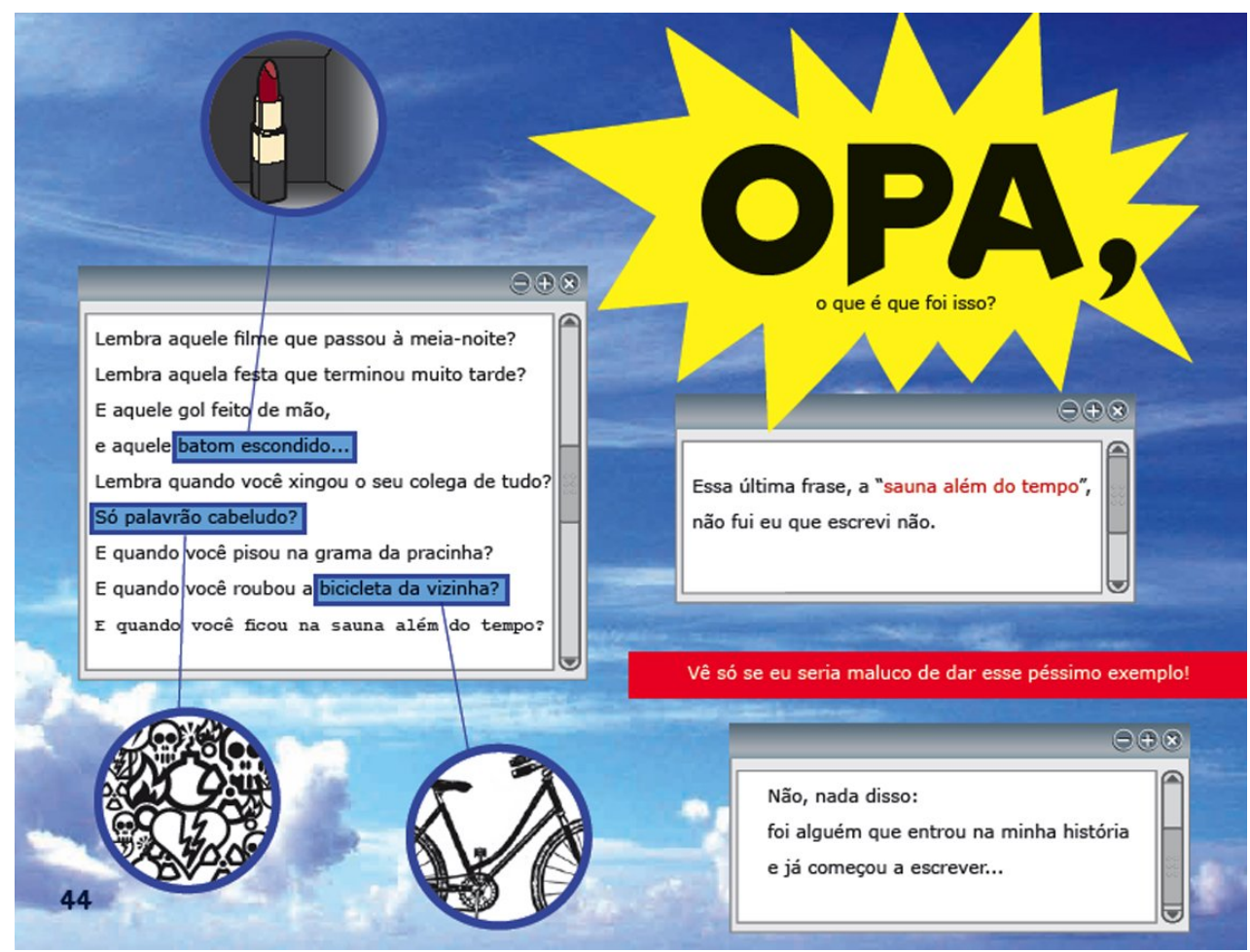


- Os hackers:

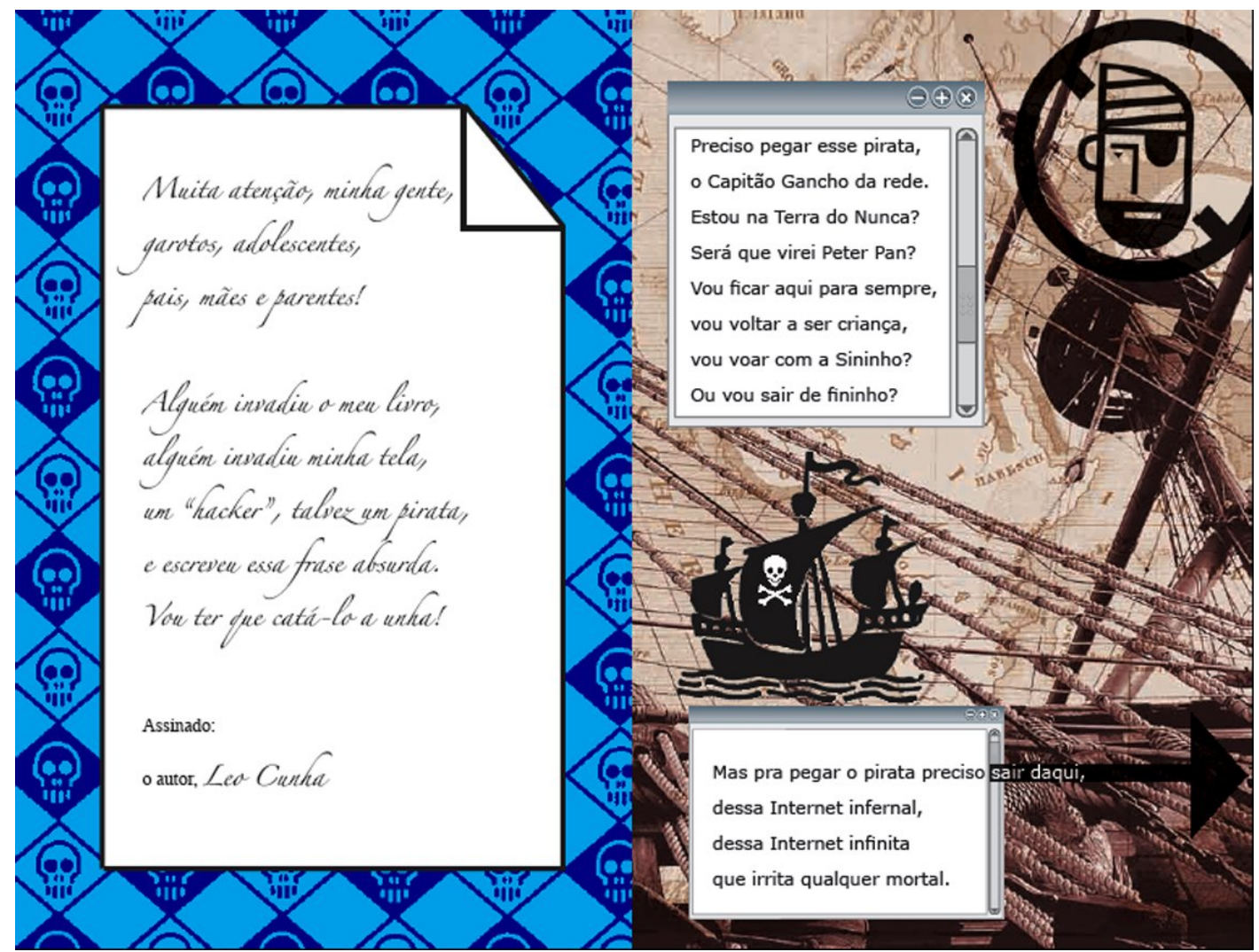

- Os vírus virtuais:

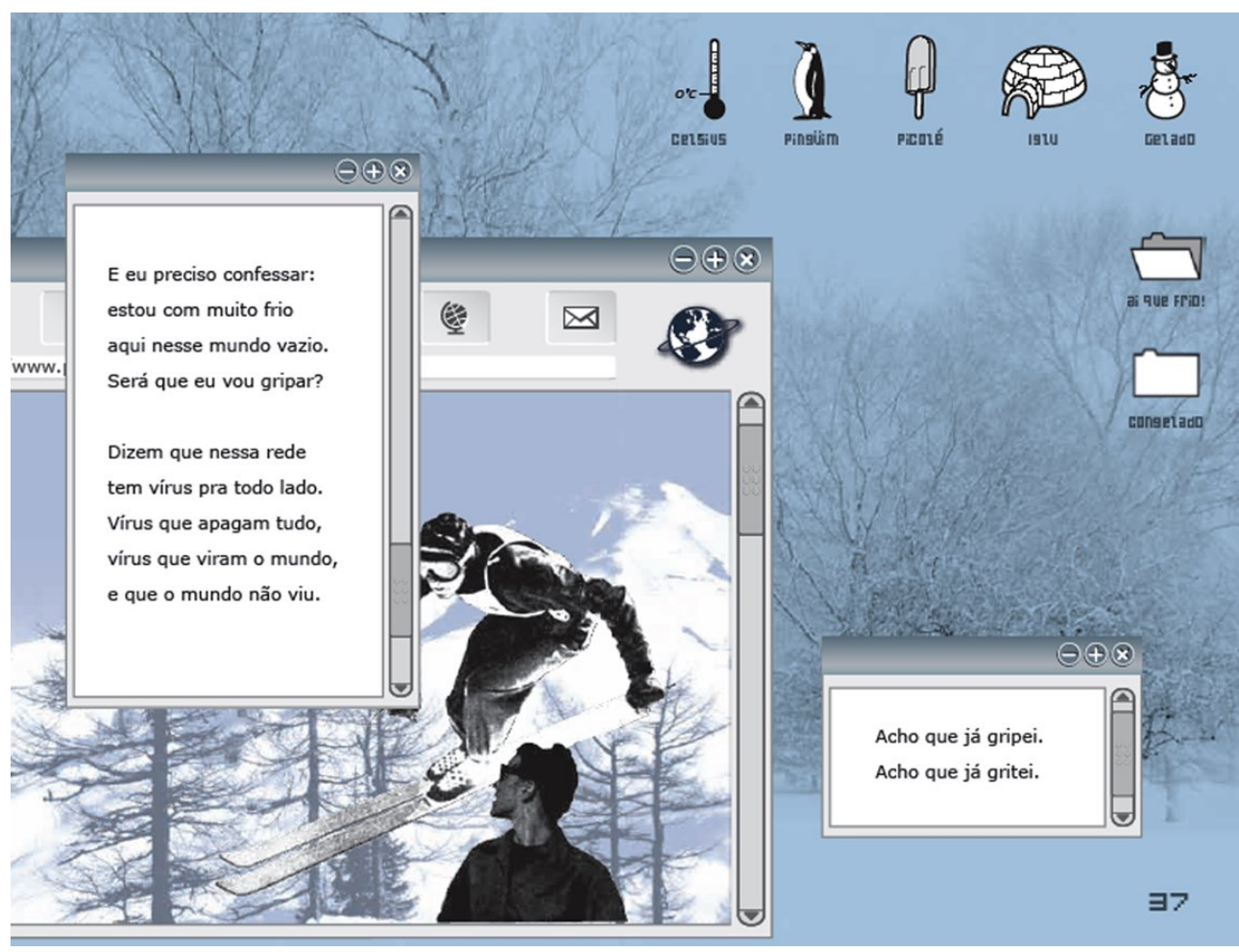


Ao final, quando já está quase desistindo de escapar daquele ciberespaço, Leo Cunha tem uma última idéia que, aparentemente, vai resolver seu problema:

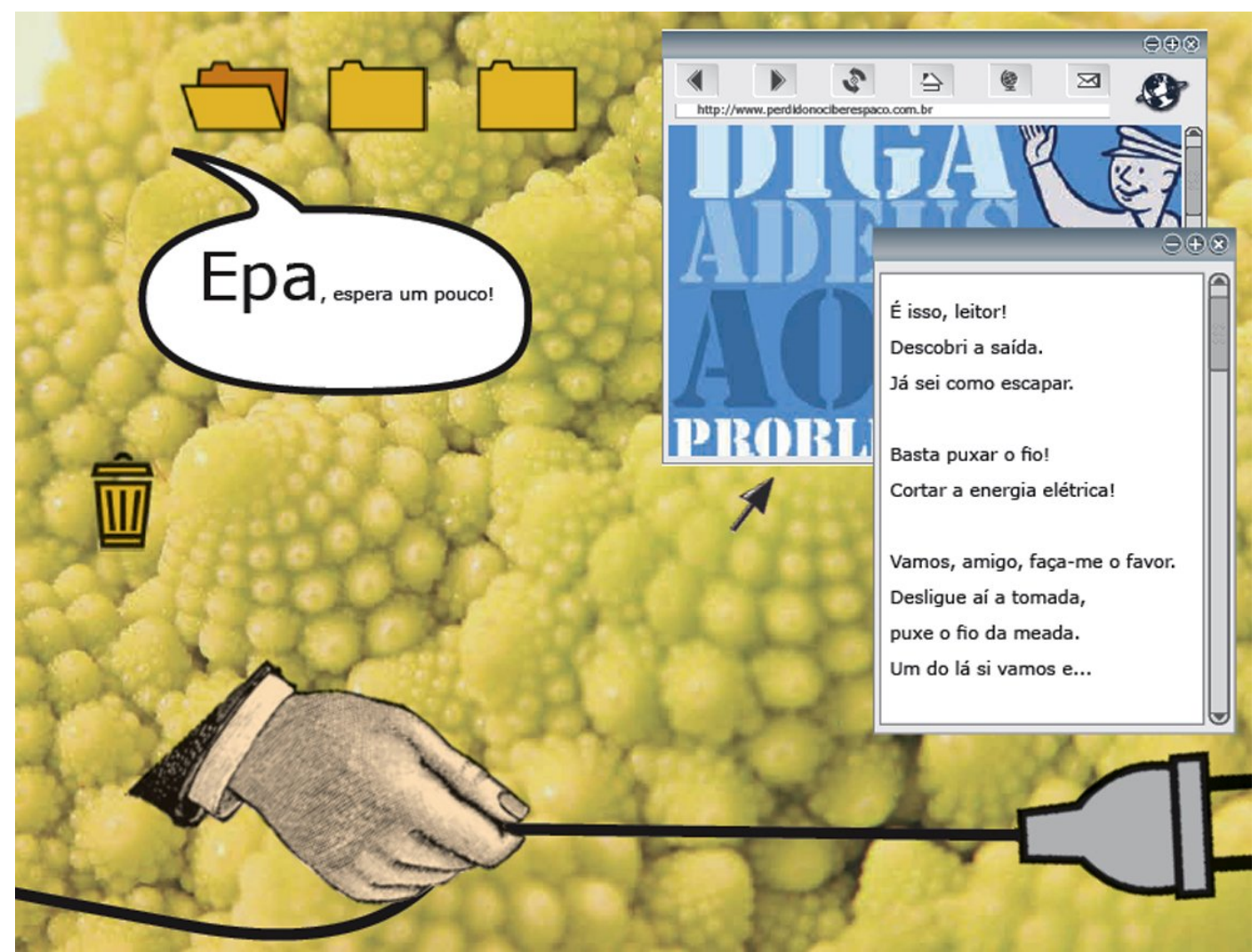

\section{FIN I}


Mas as últimas páginas vão remeter a outro aspecto do ciberespaço: o fato de que as obras tendem a uma perpétua reciclagem e recriação, e não ao fechamento. Assim, o livro se encerra de forma cíclica, num recomeço do jogo:
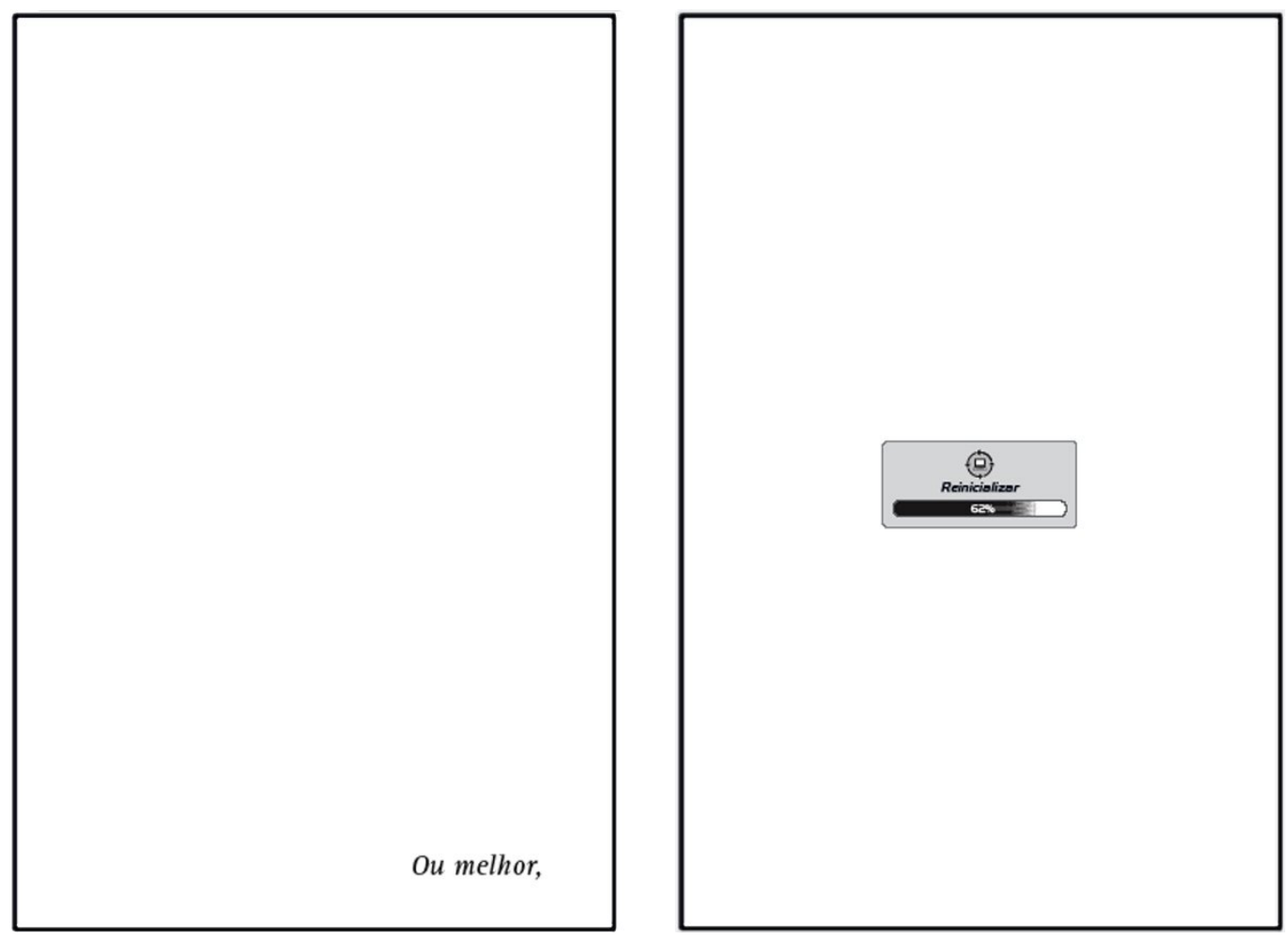

Vale ressaltar, por fim, que Perdido no ciberespaço não é o único livro de literatura infantojuvenil a apostar fundo na convergência entre o objeto livro e o universo virtual. Almir Correia, por exemplo, criou o interessante Blog do sapo Frog, que, além do diferencial do texto poético, também explora alguns elementos da Internet, como as conexões hipertextuais e a diagramação típica de um blog. ${ }^{5}$

Em Mano descobreo@mor, de Gilberto Dimenstein e Heloísa Prieto, a trama aborda os diversos perigos e segredos na vida de um jovem, incluindo a Internet como um elemento importante de seu cotidiano, principalmente no que diz respeito às amizades virtuais. O projeto gráfico do livro também cria um hibridismo entre linguagens, ao mesclar ilustrações mais tradicionais (mostrando os personagens) a imagens das telas que os personagens (e o leitor) veem, e ainda trechos em formato de história em quadrinhos.

De todo modo, fica a sensação de que os livros de literatura infantojuvenis ainda têm muito a explorar neste diálogo textual e imagético entre as páginas e as telas.

\footnotetext{
${ }^{5}$ No campo da poesia, é importante destacar, também, a produção de Sérgio Capparelli, que, como poeta e estudioso da cibercultura, testou os limites entre a publicação impressa e eletrônica em livros como Poesia Visual (em parceria com Ana Gruszinsky) e 33 ciberpoemas e uma fábula virtual.
} 


\section{Referências}

AGUIAR, Luiz Antonio. Internautas - os chips reinventando o nosso dia a dia. São Paulo: Melhoramentos, 2011.

ALBERGARIA, Lino de. De Paris, com amor. São Paulo: Saraiva, 1997.

ALBERGARIA, Lino de; SOUZA, Angela Leite de. Sinos_e_queijos.com. Belo Horizonte: Dimensão, 2010.

ANDRADE, Telma Guimarães Castro. Coração na rede. São Paulo: Atual Editora, 1999.

BANTOCK, Nick. Griffin e Sabine - uma correspondência extraordinária. São Paulo: Marco Zero, 1994.

BARDARI, Sersi. A alquimia do "adultescer": a literatura para juventude como rito de passagem. Tese de Doutorado em Letras. São Paulo: USP, 2008.

BRAZ, Júlio Emílio; VIEIRA, Janaína. Só entre nós - Abelardo e Heloísa. São Paulo: Saraiva, 2000.

CABOT, Meg. O diário da Princesa. Rio de Janeiro: Record, 2002.

CAPPARELLI, Sérgio. 33 ciberpoemas e uma fábula virtual. Porto Alegre: L\&PM, 1998.

CAPPARELLI, Sérgio; GRISZINSKI, Ana. Poesia visual. São Paulo: Global,

CLAVER, Ronald; VIANA, Vivina de Assis. Ana e Pedro. São Paulo: Atual, 1990.

CORREIA, Almir. Blog do sapo Frog. Belo Horizonte: Formato, 2007.

COSTA, Silvana. Amigos pra cachorro. Belo Horizonte: Dimensão, 2005.

CUNHA, Leo. O hipertexto como novo espaço para a narrativa literária. Dissertação de Mestrado em Ciência da Informação. Belo Horizonte: UFMG, 1999. 
CUNHA, Leo. Perdido no ciberespaço. São Paulo: Larousse, 2007.

DIMENSTEIN, Gilberto; PRIETO, Heloísa. Mano descobre o @mor. São Paulo: Senac, 2002.

DOUBROVSKY, Serge. Fils. Paris: Gallimard, 2001.

FRANK, Anne. O Diário de Anne Frank. Edição Integral. Rio de Janeiro: Record, 1997.

GARCIA, Edson Gabriel. Diário de Biloca. São Paulo: Atual, 1994.

LANDOW, George P. Hypertext: the convergence of contemporary critical theory and technology. London: John Hopkins, 1992.

MACFARLANE, Aidan; MCPHERSON, Ann. Diário de um adolescente hipocondríaco. São Paulo: 34, 1987.

MORLEY, Helena. Minha vida de menina. São Paulo: Cia das Letras, 1998.

PERISSĖ, Heloísa. O diário de Tati. Rio de Janeiro: Objetiva, 2003.

SCLIAR, Moacyr. Ataque do comando P.Q. São Paulo: Ática, 2004.

TORERO, José Roberto. O diário do Lelê. São Paulo: Salamandra, 2009.

VIANA, Vivina de Assis. Sabe de uma coisa?: diário de uma adolescente. São Paulo: Atual, 1989. 